\title{
THE SPECIFICS OF RISK MANAGEMENT IN TOURISM SMES FROM THE POINT OF VIEW OF HUMAN RESOURCES
}

\author{
Katarína HAVIERNIKOVÁ \\ Department of Economy and Economic, Faculty of Social and Economic Relations, \\ Alexander Dubček University of Trenčín
}

Received: 06. April 2021 Reviewed: 28. May 2021 Accepted: 15. June 2021

\begin{abstract}
Ensuring the prosperity of a company in the current conditions brings various risks which SMEs must face. It is important also for tourism SMEs to apply risk management, which plays an important role in their activities and its successful implementation depends on the abilities of owners/managers. The main aim of the paper is to empirically explore the specifics of risk management in tourism SMEs from the point of view of human resources. The aspect of human resources in this paper is focused on the responsibility for risk management and the attitudes towards the used methods within the process of risk management, and the attitudes towards risk prevention by the person responsible for risk management in the company. This analysis is the result of a questionnaire survey conducted among 531 Slovak tourism SMEs. For the evaluation of respondents' answers the Chi-square test of dependency and Cramer V were used. This study found that the responsibility for risk management in SMEs lies primarily on owners of SMEs who use various risk prevention measures.
\end{abstract}

Keywords: SMEs, risk management, responsibility, human resources, risk

JEL Classification: G32, L83, L20

\section{Introduction and theoretical background}

In every developed economy, SMEs have an irreplaceable place. They create jobs, improve the competitive environment in the economy, contribute to innovation, and adapt sensitively to rapidly changing conditions, changes and market requirements. There are also greater preconditions for the more effective use of employees' unique skills, knowledge, and work habits in SMEs. There is more room to apply unique ideas and create innovations. As Helimann et al. (2020) stated, many different changes challenge the form of working life and all the activities comprising it. It is important to monitor the environment and to learn quickly, and moreover, with a focus on the future. Being motivated to learn, adopting solution-based learning and compe- 
tence management, and nurturing resilience can be very beneficial when designing the future. Attitude is crucial to SMEs. Proactivity in change processes will show the way how to be successful. Proactiveness has been found to affect performance positively in a dynamic environment to a greater extent than in a stable environment, for change and un-certainty provide better conditions to find new opportunities whose benefits outweigh their risks and costs (Kallmuenzer, 2019).

Tourism is a dynamically developing sector with a cross-sectional character, where it is difficult to prove its economic benefits (Gúčik, 2011). According to Palatková (2014), tourism is built on SMEs, which play a crucial role in providing appropriate products and services to tourists, responding to their most specific requirements. At the same time, SMEs belong to business entities that create economic structures in individual regions. They are the force of economic growth and, simultaneously, the mediators of further development (Havierniková, 2020). Previous research, also conducted within the tourism industry, showed that most tourism entrepreneurs view proactiveness as an essential entrepreneurial quality for tourism firms (Kallmuenzer, 2019).

The activity of SMEs in tourism is influenced by various problems that require risk management initiatives. Risk management is an integral part of the decision-making process and enables every SME to be resilient and agile in dealing with the consequences of unforeseen events (Crovini, 2019). As Suttipun et al. (2018) state, risk management can help increase shareholder and investor confidence by implementing a process that allows stabilizing financial and non-financial results and helps to understand stakeholders in the company's affairs. Risk management generally refers to risks that come mainly from the external and internal environment of the company. However, the extent of uncertainties considered a management need had increased significantly in the business environment. The situation in connection with the global pandemic COVID 19 also contributed to this. The problem faced by the SMEs is that COVID-19 has moved from a health crisis to an economic crisis. Business owners are fervently trying to survive both situations, almost certainly with lesser resources (Al-Fadly, 2020). Therefore, the new wave of risk management in SME businesses can be considered a defensive response to an increasingly challenging environment (Crovini et al., 2020).

The application of risk management in SMEs also has its specifics in responsibility for risk management, mainly related to their size and organizational structure. There is a wide range of studies in the literature focused on risk management in SMEs, but only a few (e.g., Boholm, 2010; Gilmore et al., 2004; Hudáková and Dvorský, 2018, Klučka and Grünbichler, 2020) focus on responsibility for risk management. In micro and small enterprises, owners or managers have the highest responsibility for risk management because it is not adequate for these enterprises to employ a person responsible for risk management. There are many managers in medium-sized companies, among whom responsibilities are also divided. SMEs do not have sufficient financial resources to invest in a broader form of risk management, and therefore the responsibility for decision-making in this area remains the prerogative of a competent person, but decision-making may lack professional qualities (Croviny, 2019).

One of the specific fearures of SMEs is that they allow people to learn to use their business skills. Therefore, the success of an SME depends on the ability of the person responsible for managing the business. From this specific perspective, managerial practices are an important assumption for a successful employees' management and mainly their work performance (Korauš et al., 2017). Without qualified and competent managers, no activity will be performed effectively. It is similar in the case of risk management. The person responsible for risk management should know how risks can be identified, monitored, and managed, reducing their negative impact. Lack of knowl- 
edge is a fundamental problem of the failure of most initiatives in SMEs, and lack of experience can become a significant risk to business survival. The goal of the person responsible for risk management should be to be able to eliminate risks so that the SME gets into a situation where it can anticipate changes and be able to respond to them and use them to its advantage (Havierniková, 2020).

The business-related literature also addresses entrepreneurs' attitudes to risk and the methods used to identify and manage them. The identification of risks and their management is a crucial task of strategic management. Risk identification is usually a prerequisite for later risk management (Falkner \& Hiebel, 2015). The right and early identification of risk sources can help companies to survive not only during a crisis period (Virglerova et al., 2020). Risk identification and assessment are generally carried out formally, but the experience needs to be built on and given intuition to a certain extent. The methods used in the risk management process, according to Haviernikova (2019), Lima et al. (2020) include Estimation, Quality Management, Balance Scorecard (BSC), Interviews with Employees, Error and Flow Analysis Method, SWOT Analysis, and Brainstorming.

Every entrepreneur has specific "parameters" (Wang and Poutziouris, 2010) such as age, education, length of experience in the field, family background and others, which play an essential role in his business and attitude to risk. The entrepreneur can avoid risk (averse attitude), is not interested in risk (neutral) or takes the risk (risk propensity). The person responsible for the company's management must be familiar with the possible risks and and with how it is possible to reduce the risk in implementing the business plan. Smejkal and Rais (2013), Hudáková et al. (2019) list the following risk mitigation methods: risk reduction, risk transfer, risk insurance, risk avoidance and risk retention. Risk reduction measures focus on risk prevention (preventive, offensive measures) or mitigation of adverse effects (corrective, defensive measures).

The novelty of this paper can be summarised as follows: (1) this paper extends the knowledge about risk management in a specific economic branch with a focus on human resources, as well as(2) it provides the brief study with a focus on the general aspects of risk management in tourism SMEs.

In the following part of the paper, we focus on areas related to risk management specifics with an orientation towards tourism SMEs. The document is structured as follows. The material and methodology section describes the procedure for conducting a questionnaire survey, respondents' structure, and an explanation of the methods used to process the data obtained. The results and discussion section provides the results obtained in confrontation with other studies. Finally, the accepted conclusions and the implications for further research are evaluated.

\section{Material and methods}

In the light of the past research discussed above we conducted a questionnaire survey that focused on several issues related to risk management in SMEs. The survey was conducted among tourism SMEs in 2018-2019. The interviewed ones were entrepreneurs and managers of selected SMEs. SMEs were selected randomly and were addressed directly by email, or personally and they were asked to complete the questionnaire. We calculated the minimal valid sample size necessary for this research within a priory analysis executed in the chi-square tests' $\mathrm{G}^{*}$ power software. The sample of 341 SMEs was calculated, when the power $(1-\beta$ err prob $)=0.80$, effect size $\mathrm{w}=0.20$, and a err prob $=0.05$. This implies an $80 \%$ chance of correctly rejecting the hypothesis of 
no difference between expected and observed proportions with 341 participants. The questionnaires were completed by 531 owners/manager of SMEs.

A research question (RQ) was poposed, in which we focused on the selected specifics of risk management: responsibility for risk management, methods used to identify risks and the attitude of entrepreneurs to risk

\section{RQ1: What are the specifics of risk management in SME tourism?}

To this research question, we established a null and alternative statistical hypothesis to calculate the Chi-square test of independence.

H0: The perception of selected specifics of risk management does not depend on the size category of the company.

H1: The perception of selected specifics of risk management depends on the size category of the company.

We used the Chi-square of independence to test the statistical hypotheses, and the test was performed at a significance level of $\alpha=0.05$. If the examination reveals a relationship between statistical features $(p \leq 0.05)$, it makes sense to determine the degree of dependence. The dependence is considered to be stronger the closer the obtained absolute value is to 1 (Mihalčová et al., 2021). For this purpose, we used the Cramer V coefficient, which takes values from $<0.1>$. The closer the importance of this coefficient is to 1 , the stronger the dependence. The calculations were performed in the STATISTICA 12 software.

\section{Results and discussion}

The research sample consisted of 531 respondents from eight self-governing regions. The characteristics of SMEs involved into the research in terms of basic characteristics can be seen in Table 1 . The majority of respondents came from micro-enterprises $(52.35 \%)$, and the fewest from medium-sized enterprises $(7.34 \%)$. Regarding regional representation, the survey was attended the most by SMEs from Žilina Region (23.16\%) and the least from Banská Bystrica Region.

Table 1 Research sample

\begin{tabular}{|c|c|c|c|c|c|c|c|c|c|}
\hline Size category & BA & TT & TN & NR & ZA & BB & PO & KE & Total \\
\hline $\begin{array}{c}\text { Micro } \\
\text { (0-9 employees) }\end{array}$ & $2,45 \%$ & $4,14 \%$ & $13,37 \%$ & $1,51 \%$ & $23,16 \%$ & $1,13 \%$ & $4,90 \%$ & $1,69 \%$ & $52,35 \%$ \\
\hline $\begin{array}{c}\text { Small } \\
\text { (10-49 employees) }\end{array}$ & $2,82 \%$ & $2,82 \%$ & $10,36 \%$ & $1,32 \%$ & $15,82 \%$ & $1,13 \%$ & $4,33 \%$ & $1,69 \%$ & $40,30 \%$ \\
\hline $\begin{array}{c}\text { Medium (50-249 } \\
\text { employees) }\end{array}$ & $2,26 \%$ & $0,56 \%$ & $1,13 \%$ & $0,00 \%$ & $2,45 \%$ & $0,00 \%$ & $0,94 \%$ & $0,00 \%$ & $7,34 \%$ \\
\hline Total & $7,53 \%$ & $7,53 \%$ & $24,86 \%$ & $2,82 \%$ & $41,43 \%$ & $2,26 \%$ & $10,17 \%$ & $3,39 \%$ & $52,35 \%$ \\
\hline
\end{tabular}

Source: own research

In Table 2, we can see who bears the most significant responsibility for risk management in SMEs. In up to $92.47 \%$ of tourism SMEs, the owner or manager of the company is responsible for risk management. Only $0.56 \%$ of respondents use an exter- 
nal expert to implement risk management. Similar results are reported by Klučka and Grünbichler (2020), according to which more than 75\% of Slovak SMEs state that they do not have employees who are trained or educated in the field of risk management. Similar results were confirmed by the study of Henschel and Durst (2016), in which, regarding the responsibility for the implementation and reviewing of risk management, he found that all firms have low scores. And the risk management process is more differentiated compared to the risk management organisation, in particular the assignment of responsibilities and duties. This may be partly related to Gilmore et al., 2004, in which it is stated that SME owners fear the leakage of important information.

The answers obtained from the respondents in the survey to this question, which related to the description of the specifics of risk management, could not be subjected to statistical analysis due to failure to meet the assumptions needed to calculate the Chi-square test of independence.

Table 2 Responsibility for risk management in tourism SMEs

\begin{tabular}{|c|c|c|c|c|c|}
\hline Size category & Owner & Manager & Board member & $\begin{array}{c}\text { External } \\
\text { professionals }\end{array}$ & Total \\
\hline $\begin{array}{c}\text { Micro } \\
\text { (0-9 employees) }\end{array}$ & $50,85 \%$ & $1,13 \%$ & $0,38 \%$ & $0,00 \%$ & $52,35 \%$ \\
\hline $\begin{array}{c}\text { Small } \\
\text { (10-49 employees) }\end{array}$ & $36,53 \%$ & $2,45 \%$ & $0,94 \%$ & $0,38 \%$ & $40,30 \%$ \\
\hline Medium (50-249 employees) & $5,08 \%$ & $1,51 \%$ & $0,56 \%$ & $0,19 \%$ & $7,34 \%$ \\
\hline Total & $92,47 \%$ & $5,08 \%$ & $1,88 \%$ & $0,56 \%$ & \\
\hline
\end{tabular}

Source: own research

In the survey, SME owners also assessed how often they use the risk identification methods listed in Graph 1 and Table 3 on a scale of 1-4 (1 - always, 2 - very often, 3-rarely, 4 - never). Graph 1 shows the percentage responses of respondents to these methods. The use of methods was rated 1-always mainly by micro-enterprises. (estimate $-15.63 \%$; quality management $-10.55 \%$, BSC $-5.27 \%$, interviews with employees $-23.92 \%$, method of analysis of errors and flows $-9.23 \%$, SWOT analysis $-8.66 \%$ and brainstorming $-7.16 \%$ ). As stated by many scholars, there are only a few studies about risk management in SMEs, regardless of the fact that it is a developing topic; in particular, the general understanding of RM in SMEs is not univocal and the research on implementations, methods and practice is scant (Lima et al., 2020)

Figure 1 The assessment of used methods (\%)

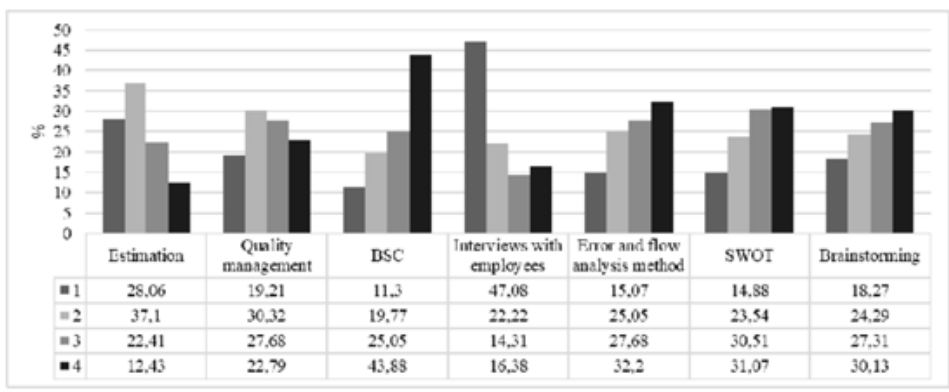

Source: own research 
The Chi-square test results and the Cramer coefficient for respondents' answers are shown in Table 3. The calculated data show that the use of the methods: Error and flow analysis method $(\mathrm{p}=0.04 ; \mathrm{V}=0.11)$, SWOT analysis $(\mathrm{p}=0.02 ; \mathrm{V}=0.12)$ and Brainstorming $(\mathrm{p}=0.00 ; \mathrm{V}=0.15)$ in the identification of risks in the company, depends on the size category of the company.

The results of $\mathrm{p}$ - levels, which in all cases are higher than the determined level of significance $(p>0.05)$ in Table 3, showed that we do not reject the null hypothesis of independence between respondents' responses according to size category when evaluating the remaining methods. This means that respondents' answers do not depend on which size category the respondents belong to.

Table 3 Methods used in the risk management process in tourism SMEs

\begin{tabular}{|l|l|l|}
\hline Method & Chi square $\left(\mathrm{p}^{*}\right)$ & Cramer V \\
\hline Estimation & 0,34 & - \\
\hline Quality management & 0,14 & - \\
\hline Balance Scorecard & 0,06 & - \\
\hline Interview with employees & 0,39 & - \\
\hline Error and flow analysis method & $\mathbf{0 , 0 4}$ & $\mathbf{0 , 1 1}$ \\
\hline SWOT analysis & $\mathbf{0 , 0 2}$ & $\mathbf{0 , 1 2}$ \\
\hline Brainstorming & 0,00 & $\mathbf{0 , 1 5}$ \\
\hline
\end{tabular}

Source: own calculation (STATISTICA)

Business managers must be able to identify the main risks, create the right context for discussion, and put forward suggestions for preventive action, with a focus on avoiding business crises (Oláh et al., 2019, Belás et al., 2018). The diagnostics of risk sources in SMEs is the most important phase of risk management because preventive actions can only be devised to eliminate the identified risk (Dvorský et al., 202, Gorzen-Mitka, 2019).

In the survey, we then found out how respondents prevent risk in their activities. When commenting on this question, respondents could identify several of the following options:

A. we also accept the risk as it is

B. we take various preventive measures

C. we reduce the severity of the consequences of risks additionally

D. we do not eliminate the causes of risks, but attention is paid to reducing the negative consequences of risks

E. we do not carry out risk activity

The results of how respondents prevent risk are shown in Table 4. The most frequently indicated option was option $\mathrm{C}$ - we reduce the severity of risks. Additionally, we implemented various preventive measures, identified as the most important by up to $55.37 \%$ of respondents. It follows from the above that SMEs address risks, despite the imperfections in applying risk management. Similarly, in their study, Alroaia and Baharun (2018) concluded that risk-taking belongs to the important characteristics of successful entrepreneurs. 
Table 4 Risk prevention

\begin{tabular}{|c|c|c|c|c|c|}
\hline Use & $\mathbf{A}$ & $\mathbf{B}$ & $\mathbf{C}$ & $\mathbf{D}$ & $\mathbf{E}$ \\
\hline Yes & 16,38 & 55,37 & 11,30 & 9,98 & 6,40 \\
\hline No & 83,62 & 44,63 & 88,70 & 90,02 & 93,60 \\
\hline p value & $\mathbf{0 , 0 1}$ & $\mathbf{0 , 0 0}$ & $\mathbf{0 , 0 5}$ & 0,11 & 0,19 \\
\hline Cramer V & $\mathbf{0 , 1 2}$ & $\mathbf{0 , 0 0}$ & $\mathbf{0 , 1 1}$ & - & - \\
\hline
\end{tabular}

Source: own calculation (STATISTICA)

The calculated $\mathrm{p}$ - level values using the Chi-square test showed $(\mathrm{p}>0.05)$ that we do not reject the null hypothesis only in the case of option D - we do not eliminate the causes of risks but pay attention to reducing the negative consequences of risks and do not implement $\mathrm{E}$ - risk activity. We state that there is no significant dependence between the respondents' answers according to the company's size category. A statistically significant dependence on the method of risk prevention can be observed in options A, B, C, while in terms of significance based on the results of Cramer's V, there is only a weak dependence.

\section{Conclusion}

The paper's subject is the systematization of the acquired knowledge in combination with the results of a questionnaire survey, the results of which point to the specifics of risk management with a focus on tourism SMEs. The application of risk management in these companies is significantly associated with human resources. SME owners must learn to work with risk to the extent appropriate to apply the risk management process. To do this, it is necessary to have proper knowledge and use the knowledge already gained from previous activities related to the application of risk management in SMEs. The limitation of this study was the focus on the brief aspects of risk management context in connection with human resources. For this reason, another direction of research in this area is to focus on specific aspects related to human resources in tourism SMEs as trust, knowledge and work experience affect the success of the $\mathrm{SME}$ in the context of risk management.

\section{Acknowledgement}

This research was supported by the project, which has received funding from the Ministry of Education of the Slovak Republic and of Slovak Academy of Sciences with title "Assessment changes in the qualitative structure of international economic relations under the influence of Industry 4.0 with implications for the EU and Slovak economic policies". Project registration number Reg. No. VEGA [1/0462/20].

\section{Bibliography}

1. Al-Fadly, A. (2020). Impact of COVID-19 on SMEs and employment. Entrepreneurship and Sustainability Issues, 8(2), 629-648. http:/ / doi.org/10.9770/ jesi.2020.8.2(38)

2. Alroaia, Y. V., \& Baharun, R. B. (2018). Identification and prioritizing influential 
factors on entrepreneurial success: A case study of SMEs in Iran and Malaysia. Polish Journal of Management Studies, 17(2), 31-40.

3. Belás, J., Smrcka, L., Gavurova, B., \& Dvorsky, J. (2018). The impact of social and economic factors in the credit risk management of SME. Technological and Economic Development of Economy, 24(3), 1215-1230. https://doi.org/10.3846/ tede.2018.1968.

4. Boholm, A. 2010. On the organizational practice of expert-based risk management: A case of railway planning. Risk management, 12(4), 235-255.

https://doi.org/10.1057/rm.2010.4.

5. Crovini, C. 2019. Risk management in small and medium enterprises. Oxon: Routledge. 106 s. ISBN 978-0-367-22679-4.

6. Crovini, C., Ossola, G. \& Britzelmaier, B. (2020). How to Reconsider Risk Management in SMEs? An Advanced, Reasoned and Organised Literature Review. European Management Journal, 39(1), 118-134. https:/ / doi.org/ 10.1016/ j.emj.2020.11.002.

7. Dvorsky, J., Belas, J., Gavurova, B., \& Brabenec, T. (2020). Business risk management in the context of small and medium-sized enterprises. Economic Research-Ekonomska Istraživanja, 1-19. https://doi.org/10.1080/133167 7X.2020.1844588

8. Falkner, E. M., \& Hiebl, M. R. (2015). Risk management in SMEs: a systematic review of available evidence. The Journal of Risk Finance, 16(2), 122-144. https://doi.org/ 10.1108/JRF-06-2014-0079

9. Gilmore, A., Carson, D. \& O`Donnell, A. (2004). Small business owner-managers and their attitude to risk, Marketing Intelligence \& Planning, 22 (3), 349-360.

10. Gorzen-Mitka, I. (2019). Interpretive structural modeling approach to analyze the interaction among key factors of risk management process in SMEs: Polish experience. European Journal of Sustainable Development, 8(1), 339-349. https://doi.org/10.14207/ejsd.2019.v8n1p339

11. Gúčik, M. (2011). Cestovný ruch-Politika a ekonómia. Banská Bystrica: Dali-BB. 188 s. ISBN 978-80-89090-98-3

12. Havierniková, K. a kol. (2018) Manažment rizík malých a stredných podnikov v kontexte zapojenia do činnosti klastrov v Slovenskej republike. Trenčín: FSEV, TnUAD, 164 s. ISBN 978-80-8075-822-6.

13. Havierniková, K. (2020). Manažment rizík malých a stredných podnikov a klastrová spolupráca. Trenčín: FSEV, TnUAD, 170 s. ISBN 978-80-8075-939-1.

14. Heilmann, P., Forsten-Astikainen, R., \& Kultalahti, S. (2020). Agile HRM practices of SMEs. Journal of Small Business Management, 58(6), 1291-1306. https://doi.org/10.1111/jsbm.12483.

15. Hudáková, M. \& Dvorský, J. (2018). Assessing the risks and their sources in dependence on the rate of implementing the risk management process in the SMEs. Equilibrium. Quarterly Journal of Economics and Economic Policy, 13(3), 543-567. https://doi.org/10.24136/eq.2018.027.

16. Hudáková, M., Bugánová, K., Míka, V. \& Masár, M. 2019. Manažment rizík malých a stredných podnikov. Žilina: EDIS-vydavatel'ské centrum ŽU. 202 s. ISBN - 978-80-554-1518-5

17. Kallmuenzer, A., Kraus, S., Peters, M., Steiner, J., \& Cheng, C. F. (2019). Entrepreneurship in tourism firms: A mixed-methods analysis of performance driver configurations. Tourism Management, 74, 319-330. https:// doi.org/10.1016/j.tourman.2019.04.002

18. Klučka, J. \& Grünbichler, R. (2020). Enterprise Risk Management-Approaches 
Determining Its Application and Relation to Business Performance. Quality Innovation Prosperity, 24(2), 51-58. https://doi.org/10.12776/QIP.V24I2. 1467.

19. Korauš, A., Kaščáková, Z., Parová, V., Veselovská, S. (2017). Sustainable economic development through human resource management: social intelligence of managers and performance. Journal of Security and Sustainability Issues, 6(3), 457-477. https://doi.org/10.9770/jssi.2017.6.3(11)

20. Lima, PFD, Crema, M., \& Verbano, C. (2020). Risk management in SMEs: A systematic literature review and future directions. European Management Journal, 38(1), 78-94.

21. Mihalčová, B., Korauš, A., Prokopenko, O., Hvastová, J., Freňáková, M., Gallo, P., Balogová, B. (2021) Effective Management Tools for Solving the Problem of Poverty in Relation to Food Waste in Context of Integrated Management of Energy. Energies, 14, 4245. https:/ / doi.org/10.3390/en14144245

22. Oláh, J., Kovács, S., Virglerova, Z., Lakner, Z., Kovacova, M., \& Popp, J. (2019). Analysis and comparison of economic and financial risk sources in SMEs of the Visegrad group and Serbia. Sustainability, 11(7), 1853. https://doi.org/10.3390/ su11071853.

23. Palatková, M. (2014). Mezinárodní turizmus. 2. aktualizované a rozšířené vydání. Praha: Grada Publishing., a.s. 256 s. ISBN 978-80-247-4862.

24. Smejkal, V. a Rais, K. (2013). Řízení rizík ve firmách a jiných organizacích. 4. vydaání. Praha: Grada Publishing, 488 s. ISBN 978-80-247-4644-9.

25. Suttipun, M., Siripong, W., Sattayarak, O. A., Wichianrak, J., \& Limroscharoen, S. (2018). The Influence of Enterprise Risk Management on Firm Performance Measured by the Balanced Scorecard: Evidence from SMEs in Southern Thailand. ASR:CMU Journal of Social Sciences and Humanitites, 5(1), 33 - 53. https//doi.org/ 10.12982/CMUJASR.2018.0002.

26. Wang, Y. \& Poutziouris, P. (2010). Entrepreneurial risk taking: empirical evidence from UK family firms. International Journal of Entrepreneurial Behavior \& Research, 16(5), 370-388. https:/ / doi.org/10.1108/13552551011071841.

27. Virglerova, Z., Dvorsky, J., Kozubikova, L., \& Cepel, M. (2020). Perception of nonfinancial risk determinants in SMEs in Visegrad countries. Oeconomia Copernicana, 11(3), 509- 529. doi: 10.24136/oc.2020.021

Correspondence address:

Ing. Katarína Havierniková, PhD. Department of Economy and Economics, Faculty of Social and Economics Relations, Alexander Dubček University of Trenčín, Študentská 3, 91150 Trenčín, Slovakia, email: katarina.haviernikova@tnuni.sk 